\title{
Rediscovery of the Timor Bush Warbler Locustella timorensis on Alor and Timor, Wallacea: clarifying taxonomic affinities, defining habitat and survey recommendations
}

\author{
COLIN R. TRAINOR, PHILIPPE VERBELEN and SERGE HOSTE
}

\section{Summary}

The Timor Bush Warbler Locustella timorensis was first collected by Georg Stein on Mount Mutis, West Timor in 1932, but there have been no confirmed field observations since. Here we report on the discovery of a new population of bush warbler on Alor (9 September 2009), which prompted a search for, and subsequent rediscovery, of the nominate Timor Bush Warbler (20 December 2009) in Timor-Leste. We also undertook the first bush warbler searches in the mountains on Atauro Island, and the first ornithological exploration of the mountains of Pantar and Wetar islands. On Alor, at least 13 male bush warblers were heard singing from shrub and grass beneath woodland and forest edge at $859-1,250 \mathrm{~m}$. On Timor, at least 40 males were heard during December, April and July from tall grassland below Mount Ramelau (1,720-2,100 m), Timor-Leste. The song structure of the Alor and Timor birds is similar, and close to Javan Bush Warbler L. montis of Java and Bali, as well as to recordings of Russet Bush Warbler L. mandelli of mainland Asia and Benguet Bush Warbler L. seebohmi from the Philippines. The song of the Alor bird is substantially higher pitched (mean $\mathrm{min} / \max 3,233-4,980 \mathrm{kHz}$ ) than the Timor bird $(2,928-$ $4,76 \mathrm{I} \mathrm{kHz}$ ) and both are substantially higher pitched than Javan birds. Recordings of Russet Bush Warbler from mainland Asia are higher pitched than songs of all insular taxa, and the song of Benguet Bush Warbler is of a similar pitch to the Timor bird. Recent molecular studies have found that divergences between Javan Bush Warbler and the Russet Bush Warbler are slight, and the high degree of song similarity of the Alor and Timor populations to Javan Bush Warbler places them close to the Benguet Bush Warbler complex. The Timor Bush Warbler is recognised as Near Threatened' by IUCN, but this will require re-evaluation. On Alor, suitable habitat is extensive and under little threat, but grassland in the uplands of West and East Timor is intensively grazed and regularly burnt. Further field surveys are needed on both Timor and Alor to capture birds, clarify taxonomic relationships using molecular approaches, and further define habitat use and conservation status. Bush warblers were not recorded from Pantar, Atauro and Wetar islands.

\section{Introduction}

The Bradypterus bush warblers comprise about 25 species worldwide (del Hoyo et al. 2006) however, recent analyses show that the Asian Bradypterus species actually belong within Locustella (Alström et al. 2011). They typically inhabit hard-to-access montane regions and often have cryptic and nondescript brown plumage with skulking habits (Kennerley and Pearson 2010, Alström et al. 2011). As a consequence, comparatively few specimens exist, they are infrequently recorded and are generally poorly known, so taxonomic advances have been rather slow and complicated (Dickinson et al. 2000). In 1932, on Mount Mutis, West Timor, two bush warbler 
specimens were collected at $1,800 \mathrm{~m}$ by G. Stein. No account of this expedition was published, and Stein's original field notes were destroyed during World War II (LeCroy 2008) so no details of the ecology of this bush warbler have been published. These were described by Mayr (1944) as a subspecies of Javan Bush Warbler Locustella montis.

Javan Bush Warbler was later subsumed into the widespread polytypic Russet Bush Warbler L. seebohmi by Delacour (1952) which is now named L. mandelli with seebohmi used exclusively for the Benguet Bush Warbler of the Philippines (Dickinson et al. 2000). A recent review of Russet Bush Warbler provisionally erected the Timor population to a full species, Timor Bush Warbler L. timorensis (Dickinson et al. 2000), as well as treating the Javan form montis as specifically distinct. Most authors currently consider timorensis and montis as full species (Mayr 1944, Dickinson et al. 2000, BirdLife International 2010, Kennerley and Pearson 2010, Clements et al. 2011) though many authors have included it with Russet Bush Warbler (e.g. White and Bruce 1986). Based on mitochondrial cytochrome $b$, genetic analyses of L. montis from Java and Bali show that these have diverged little (0.6-0.7\%) and vary by only $1.3-1.7 \%$ from Russet Bush Warbler (P. Alström in litt. in Kennerley and Pearson 2010) although they occur about 2,000 km from the nearest populations in Vietnam. Timor samples were not included in the analyses (Alström et al. 2011).

Timor and Alor are major islands in the Lesser Sundas archipelago in southern Wallacea (Lesser Sundas) (Fig. I). Alor lies $3 \mathrm{I} \mathrm{km}$ north of Timor. The island of Timor now comprises two nations, including the recently independent East Timor $\left(14,608 \mathrm{~km}^{2}\right)$. West Timor $\left(15,850 \mathrm{~km}^{2}\right)$ and Alor

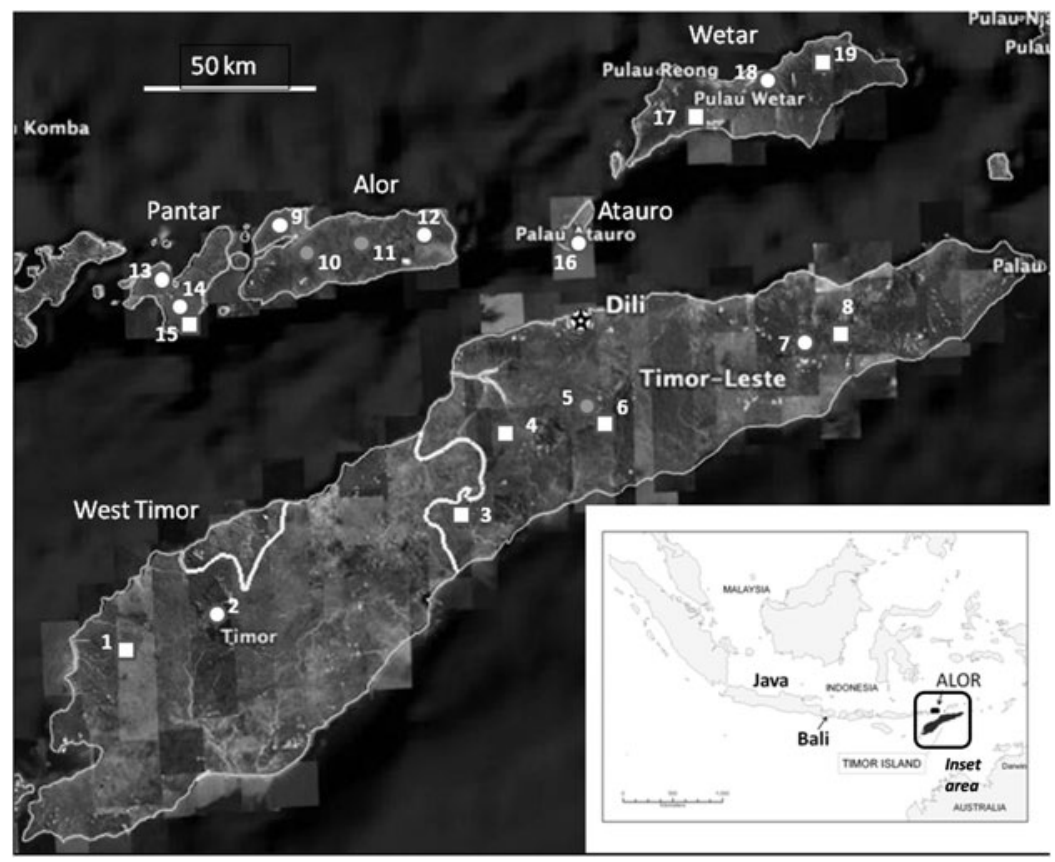

Figure 1. Map of Pantar, Alor, Timor, Atauro and Wetar showing survey sites and sites with high potential for bush warbler populations based on our understanding of bush warbler habitat use (see Discussion). Grey dot = bush warblers present; white dot = surveyed but bush warblers unrecorded; White square $=$ additional suggested survey sites for bush warblers. Sites: $1=$ Mount Timau; $2=$ Mount Mutis; $3=$ Mount Taroman $4=$ Mount Cailaco $5=$ Mount Ramelau; $6=$ Mount Cablaque; $7=$ Mount Mundo Perdido, $8=$ Mount Matebian; $9=$ Wahwah; $10=$ Mainang, $11=$ Subo-manmas; $12=$ Tanglapui Timur; $13=$ Mount Wasbila; $14=$ Mount Sirung; $15=$ Mount Delaki; $16=$ Mount Manucoco; $17=$ Tenagatu mountains $18=$ Mount Ili Mosu $19=$ Mount Lalawu/Mount Situfula. 
are part of Indonesia's East Nusa Tenggara province. On Alor, inland areas are characterised by deep knife-edged ravines, and broad upland valleys are extensive on both Timor and Alor. The highest mountains are Mount Koya Koya ( 1,825 m, Alor), Mount Mutis (West Timor) and Mount Ramelau (or 'Tatamailau', 2,963 m, Timor-Leste). Alor and Timor lie in the monsoonal tropics and have strongly seasonal climates with the dry season from May to October and wet season from November to April (RePPProT 1989). Subsistence agriculture (corn, peanuts, beans and other vegetables) and livestock grazing are the main livelihood activities of inland villages on Timor and Alor. Vegetation on Alor is dominated by evergreen tropical forest in gullies and on mountain peaks (mostly secondary regrowth); and Eucalyptus alba and E. urophylla savanna woodlands on ridges and slopes (FV and CRT unpubl. data.). Vegetation on Timor is similar, but E. urophylla woodland is more dominant in the mountains with extensive areas of short grass in the uplands (CRT unpubl. data.).

The birds of Alor have been little studied. During March to April 1896, E. Everett visited Alor, Pantar and Lembata but because of the difficulties of obtaining food, clean water and through sun exposure Hartert (1898), who worked up Everett's birds, stated that the 'collection of birds [on Alor] cannot be regarded as at all an exhaustive one'. A total of 67 bird species was listed for Alor. Everett failed to reach the mountains and collected no montane birds. The first montane birds on Alor were recorded as recently as the early 1990 os with the discovery of a new subspecies of Sunda Bush Warbler Cettia vulcannia kolisi (Johnstone and Darnell 1997) and a population of Lesser Shortwing Brachypteryx leucophrys (Holmes 1995, Trainor 2005). In contrast, Timor Island $\left(30,459 \mathrm{~km}^{2}\right)$ is substantially larger than Alor $\left(2,330 \mathrm{~km}^{2}\right)$ and has a highly endemic avifauna, which has attracted more historical (e.g. Hellmayr 1914, Mayr 1944) and modern avifaunal survey (Noske and Saleh 1996, Trainor et al. 2008, Trainor 2010). Eleven montane birds are known from Timor Island (Trainor et al. 2008, Santana et al. 2009).

There have been no further records of resident Locustella bush warblers from other Lesser Sunda islands. During August 1972, Murray Bruce reported an East Timor sighting of Timor Bush Warbler at $1,800 \mathrm{~m}$ (White and Bruce 1986). His observation of 'the lack of a supercilium' (Dickinson et al. 2000) probably excludes Timor Bush Warbler, but the 'buzzing notes [not] heard elsewhere on Timor' (in Dickinson et al. 2000) is suggestive of a Locustella bush warbler. The most substantial modern field attempt to rediscover the Timor Bush Warbler was by Paul Andrew who camped at the summit of the type locality in late March 1985. Subsequent shorter visits by Frank Rozendaal and Frank Lambert (in Dickinson et al. 200o), and a host of bird-watchers to the popular Mount Mutis area (Jepson and Ounsted 1997) have failed to rediscover Timor Bush Warbler.

In September 2009, FV discovered a population of a Locustella bush warbler in the hills (1,050 m) of central Alor, after hearing the distinctive song. To better understand the significance and taxonomic distinctiveness of the Alor bird, field searches for the Timor Bush Warbler were begun in December 2009 by CRT, with repeat visits to one site. Here we report on the discovery, and rediscovery, respectively, of the Alor and Timor bush warbler populations. Songs of the Alor and Timor birds are contrasted with the songs of Javan Bush Warbler L. montis from Java and Bali, Russet Bush Warbler L. mandelli from Thailand, Vietnam and Burma, and Benguet Bush Warbler L. seebohmi from Luzon Island, the Philippines to examine their taxonomic affinities. We provided in advance some of our field data, including recordings, to Kennerley and Pearson (2010) and here detail our observations in full. We describe distribution, abundance, habitat use, and include suggestions for future bush warbler survey in the central Lesser Sundas. We also report on the results of the first targeted searches for bush warblers from the mountains of Atauro, Pantar and Wetar islands.

\section{Methods}

\section{Study sites}

We searched for Locustella bush warblers (hereafter simply 'bush warblers') at 1o sites in total over at least 46 field days: on Alor (four sites), West Timor (one site) and East Timor (two sites), 
Pantar Island (two sites), Atauro Island (East Timor: one site) and Wetar Island (one site) (Table 1; Fig. I). Most observations were within about $3 \mathrm{~km}$ radius of these sites, but longer walks (totalling $52 \mathrm{~km}$ ) were made from Nenas to Fatumnasi ( $7 \mathrm{~km}$ at 1,350-1,850 m elevation) on 5 January 2010 in West Timor; and on Alor: Mainang to Subo-Manmas ( $17 \mathrm{~km}$ by road at $700-1,200 \mathrm{~m}$ elevation) on I1 Jan 2010; Lipa to Naumang ( $8 \mathrm{~km}$ by road at $400-805 \mathrm{~m}$ elevation) on 17 January 2010; Lipa to Lantoka ( $8 \mathrm{~km}$ by road at 700-900 m elevation) on 18 January 2010, and Mainang towards Moru (6 km by road at 400-900 m elevation) on 9 and 13 January 2010.

We surveyed by listening for the distinctive song of bush warblers and by occasionally attempting to elicit responses using playback of recordings with the aim of collecting further recordings, describing responses to playback and to facilitate photography. We did not conduct systematic playback experiments in an attempt to derive evidence of taxonomic relatedness to

Table 1. Study site details, survey dates and habitat. Refer also to Fig.1.

\begin{tabular}{|c|c|c|c|c|}
\hline Island & $\begin{array}{l}\text { Location (Site/sub-district) } \\
\text { (elevation range in } \mathrm{m} \text { ) }\end{array}$ & Coordinates & Dates & Habitat \\
\hline \multirow[t]{2}{*}{ Pantar } & $\begin{array}{l}\text { Mt Wasbila/Pantar } \\
\text { Timur/ (40o-8oo) }\end{array}$ & $\begin{array}{l}8^{\circ} 21^{\prime} 16^{\prime \prime S}, \\
124^{\circ} \mathrm{O}^{\prime} \mathrm{O} 3^{\prime \prime} \mathrm{E}\end{array}$ & 11-12 December 2009 & $\begin{array}{l}\text { Regrowth forest; } \\
\text { Eucalyptus } \\
\text { woodland; } \\
\text { grassland }\end{array}$ \\
\hline & $\begin{array}{l}\text { Mt Sirung/Pantar } \\
\text { Tengah (500) }\end{array}$ & $\begin{array}{l}8^{\circ} 29^{\prime} 26^{\prime \prime} \mathrm{S} \\
124^{\circ} \mathrm{O} 7^{\prime} 28^{\prime \prime} \mathrm{E}\end{array}$ & 14 December 2009 & $\begin{array}{l}\text { Eucalyptus } \\
\text { woodland; } \\
\text { grassland }\end{array}$ \\
\hline \multirow[t]{4}{*}{ Alor } & $\begin{array}{l}\text { Wah Wah/Alor Barat } \\
\text { Laut }(400-800)\end{array}$ & $\begin{array}{l}8^{\circ} 10^{\prime} 32^{\prime \prime} \mathrm{S}, \\
124^{\circ} 30^{\prime} 57^{\prime \prime} \mathrm{E}\end{array}$ & 21 January 2010 & $\begin{array}{l}\text { Regrowth forest; } \\
\text { tree crops }\end{array}$ \\
\hline & $\begin{array}{l}\text { Mainang/Alor Tengah } \\
(400-1,100)\end{array}$ & $\begin{array}{l}8^{\circ} 16^{\prime} 39^{\prime \prime} \mathrm{S}, \\
124^{\circ} 36^{\prime} 38^{\prime \prime} \mathrm{E} \\
\text { (north valley) } \\
8^{\circ} 18^{\prime} 20^{\prime \prime} \mathrm{S} \\
124^{\circ} 38^{\prime} 13^{\prime \prime} \mathrm{E} \\
\text { (south valley) }\end{array}$ & 9-11 January 2010 & $\begin{array}{l}\text { Evergreen forest; } \\
\text { Eucalyptus alba } \\
\text { woodland }\end{array}$ \\
\hline & $\begin{array}{l}\text { Subo-Manmas(Apui)/ } \\
\text { Alor Selatan } \\
(700-1,250)\end{array}$ & $\begin{array}{l}8^{\circ} 17^{\prime} 39^{\prime \prime} \mathrm{S}, \\
124^{\circ} 43^{\prime} 17^{\prime \prime} \mathrm{E}\end{array}$ & $\begin{array}{l}\text { 1 July 2009, } 9 \\
\text { September 2009, 4-6 } \\
\text { December 2009, } \\
\text { 14 January 2010 }\end{array}$ & $\begin{array}{l}\text { Mixed tree crops; } \\
\text { and regrowth } \\
\text { forest; } \\
\text { E. urophylla } \\
\text { woodland }\end{array}$ \\
\hline & $\begin{array}{l}\text { Tanglapui Timur/Alor } \\
\text { Timur }(400-1,200)\end{array}$ & $\begin{array}{l}8^{\circ} 14^{\prime} 56^{\prime \prime} \mathrm{S} \\
124^{\circ} 59^{\prime} 30^{\prime \prime} \mathrm{E}\end{array}$ & $\begin{array}{l}\text { 21-27 June 2009, } \\
\text { 16-18 January } 2010\end{array}$ & $\begin{array}{l}\text { Regrowth forest; } \\
\text { E. alba } \\
\text { woodland }\end{array}$ \\
\hline $\begin{array}{l}\text { West } \\
\text { Timor }\end{array}$ & $\begin{array}{l}\text { Mt Mutis/Fatumnasi } \\
\qquad(1,300-2,403)\end{array}$ & $\begin{array}{l}9^{\circ} 34^{\prime} \mathrm{O}^{\prime \prime} \mathrm{S}, \\
124^{\circ} 12^{\prime} 47^{\prime \prime} \mathrm{E}\end{array}$ & 2-5 January 2010 & $\begin{array}{l}\text { Montane forest; } \\
\text { E. urophylla } \\
\text { woodland }\end{array}$ \\
\hline \multirow[t]{2}{*}{$\begin{array}{l}\text { East } \\
\text { Timor }\end{array}$} & $\begin{array}{l}\text { Mt Ramelau/Hatu } \\
\text { Builico }(1,720-2,963)\end{array}$ & $\begin{array}{l}8^{\circ} 54^{\prime} 33^{\prime \prime} \mathrm{S} \\
\quad 125^{\circ} 31^{\prime} 28^{\prime \prime} \mathrm{E}\end{array}$ & $\begin{array}{l}\text { 20-22 December 2009, } \\
28 \text { April-1 April 2010, } \\
\text { 27-30 July } 2010\end{array}$ & $\begin{array}{l}\text { E. urophylla } \\
\text { woodland; } \\
\text { grassland }\end{array}$ \\
\hline & $\begin{array}{l}\text { Mundo Perdido/Ossu } \\
\quad(700-1,300)\end{array}$ & $\begin{array}{l}8^{\circ} 43^{\prime} 37^{\prime \prime} \mathrm{S} \\
\quad 126^{\circ} 21^{\prime} 5 \mathrm{O}^{\prime \prime} \mathrm{E}\end{array}$ & 23-24 December 2009 & $\begin{array}{l}\text { Montane forest } \\
\text { E. urophylla } \\
\text { woodland }\end{array}$ \\
\hline Atauro & $\begin{array}{l}\text { Mt Manucoco/Atauro } \\
\quad(500-995)\end{array}$ & $\begin{array}{l}8^{\circ} 15^{\prime} 53^{\prime \prime} \mathrm{S} \\
125^{\circ} 34^{\prime} 33^{\prime \prime} \mathrm{E}\end{array}$ & 27 December 2009 & $\begin{array}{l}\text { Montane forest; } \\
\text { E. alba } \\
\text { woodland }\end{array}$ \\
\hline Wetar & $\begin{array}{l}\text { Ili Moso,Gunung } \\
\text { Botak/Wetar } \\
(800-1,100)\end{array}$ & $\begin{array}{l}7^{\circ} 44^{\prime} 30^{\prime \prime} \mathrm{S} \\
126^{\circ} 15^{\prime} 38^{\prime \prime} \mathrm{E}\end{array}$ & 4-8 October 2010 & $\begin{array}{l}\text { Montane forest; } \\
\text { E. urophylla } \\
\text { woodland }\end{array}$ \\
\hline
\end{tabular}


known Locustella bush warbler populations, but did trial a variety of recordings. Songs were recorded (and played back) with an Olympus LS-10 card recorder, a ME-66 Sennheiser directional microphone and a RadioShack mini amplifier-speaker.

At each site we collected coordinates with a Garmin 6oCSx GPS within $20 \mathrm{~m}$ of all accessible birds, elevation (with Garmin GPS and Suunto wristwatch computer), and broadly described habitat type including the structure and identification of understorey and overstorey plant species. Photos were taken at each site to support habitat characterisation (and some plant species were identified from photos by the Northern Territory Herbarium, Australia). Initial observations revealed that understorey density (weedy shrub and tall grass) were important for bush warblers so we collected data on human population density, cattle plus horse density (as a measure of potential grazing pressure on grass dominated understorey) and land area for the five Indonesian sub-districts (kecamatans) where bush warblers were surveyed (comparable data for Timor-Leste was unavailable, so data from Mount Mutis was taken as representative of all Timor) from statistical reports (Badan Pusat Statistik 2009a,b).

Based on our field experiences on Alor, Timor, Pantar, Atauro and Wetar, and examination of topographic and Google Earth maps, we also identify priority sites for further bush warbler searches on Timor and neighbouring islands.

\section{Song analysis}

To describe song characteristics we selected a set of territorial song bouts (a group of strophes with a silent pause typically greater than $2 \mathrm{~s}$ between bouts) from four individual birds from Alor (measurements were obtained from 15 bouts), six individual birds from Timor (from 30 bouts), one bird from Bali (from four bouts: data were too limited to include in statistical comparisons), two birds from Java (from 1o bouts), three Russet Bush Warbler L. mandelli from Burma, Thailand and Vietnam ( 15 bouts) and three Benguet Bush Warbler L. seebohmi songs from the Philippines (15 bouts). We used good quality recordings with low background noise. In Raven Lite 1.0 software (Cornell Laboratory of Ornithology, Ithaca, New York), we measured, for each bout, the maximum and minimum frequency of a single strophe (in $\mathrm{kHz}$ ). Non-parametric Mann-Whitney $U$-test was used to determine whether there were statistically significant differences in song frequency for the populations examined. We also graphically contrast the structure of songs from Alor, Timor, Bali and Java as well as Burma, Thailand and Vietnam (Russet Bush Warbler) and Philippines (Benguet Bush Warbler) with sonograms prepared using licensed commercial software Amadeus 1.5. by Hairersoft (no filtering or noise removal algorithms were applied). Advertising and alarm calls are also described.

\section{Results}

\section{Site records}

We recorded bush warblers from two of four montane sites (Subo-Manmas and Mainang: Fig. 2) on Alor and at Mount Ramelau in Timor-Leste, on slopes above well populated inland upland valleys. Birds were heard singing during all visits in the dry and wet season on rain-days and rainfree days. At least 13 singing males were heard on Alor, and at least 40 birds were heard at Mount Ramelau (Fig. 3).

\section{Vocalisations}

\section{Song}

The songs of birds from Alor, Timor, Bali and Javan, as well as Burma, Thailand and Vietnam (Russet Bush Warbler), and the Philippines (Benguet Bush Warbler) have a broadly similar 


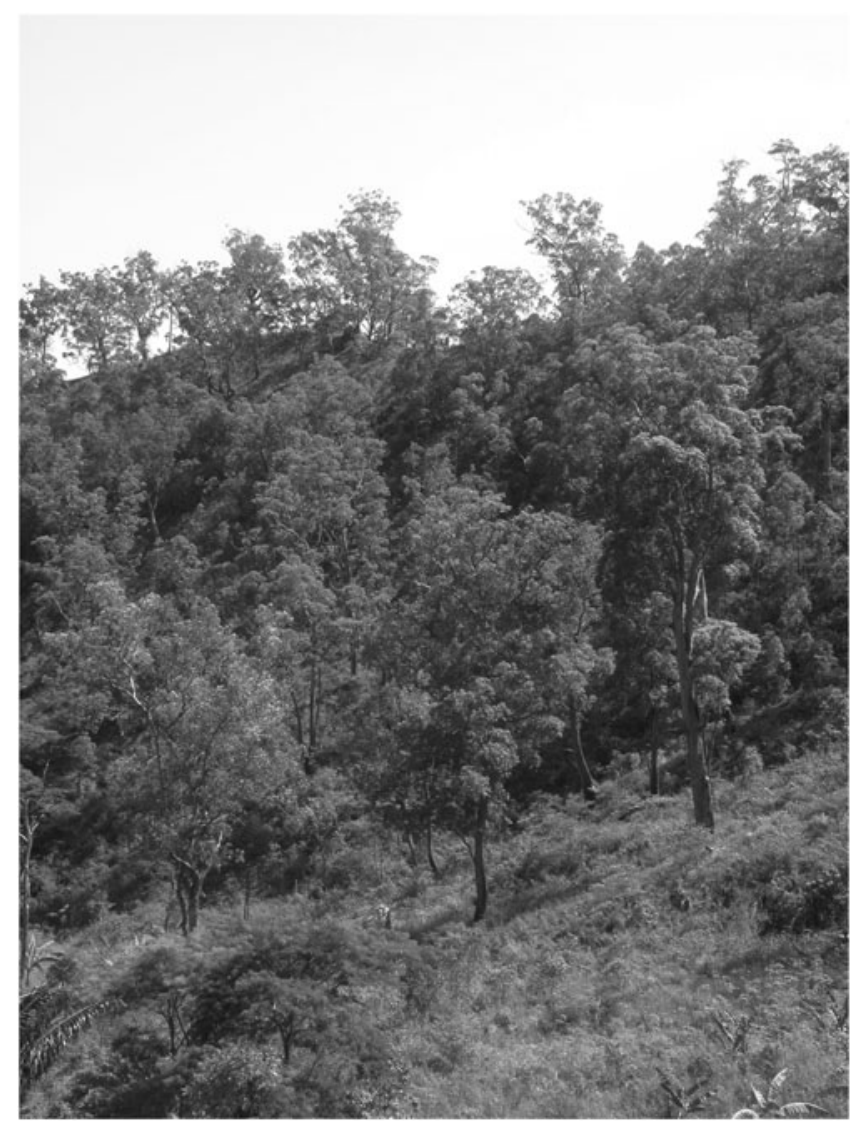

Figure 2. Eucalyptus urophylla woodland with a grassy understorey along the track between Subo and Manmas (1,150 m), Alor, where bush warblers were first recorded.

structure and comprise low-pitched $(2,500-5,900 \mathrm{KHz})$ buzzy and metallic notes which can be transcribed as zeet, zink or zureet (Figs. 5,6). Songs of Timor and Alor birds sound almost identical and produce a similar sonogram (Table 2, Fig. 4). The song strophe of Alor and Timor birds was a buzzing zureet - usually as a single syllable, or as a double syllable zu-reet. The mean maximum frequency of songs from Bali was close to those of Alor and Timor birds, but the maximum frequency of Javan songs were lower pitched (about 1 , ooo KHz lower compared to the other islands). The mean minimum frequency was substantially lower pitched in songs from Bali; songs from Javan birds were also relatively low-pitched, but mean minimum frequency were relatively high in songs from Alor and Timor. Recordings of Benguet Bush Warbler are pitched at a similar frequency to those of Timor birds, but recordings of Russet Bush Warbler (from Thailand, Burma and Vietnam) were consistently the highest pitched of those examined - with the highest mean maximum and mean minimum frequencies (Table 2, Figs. 4, 5). There was no statistically significant difference between the mean maximum frequency of Alor birds compared to Timor populations but the minimum frequency was significantly lower for Timor birds (Table 3 ). There was no statistically significant difference in the maximum frequency of Philippine birds (Benguet Bush Warbler) compared to birds from both Timor and Alor, and the mean minimum frequency of Philippine birds was only weakly significantly different to Timor birds (Table 3). There 


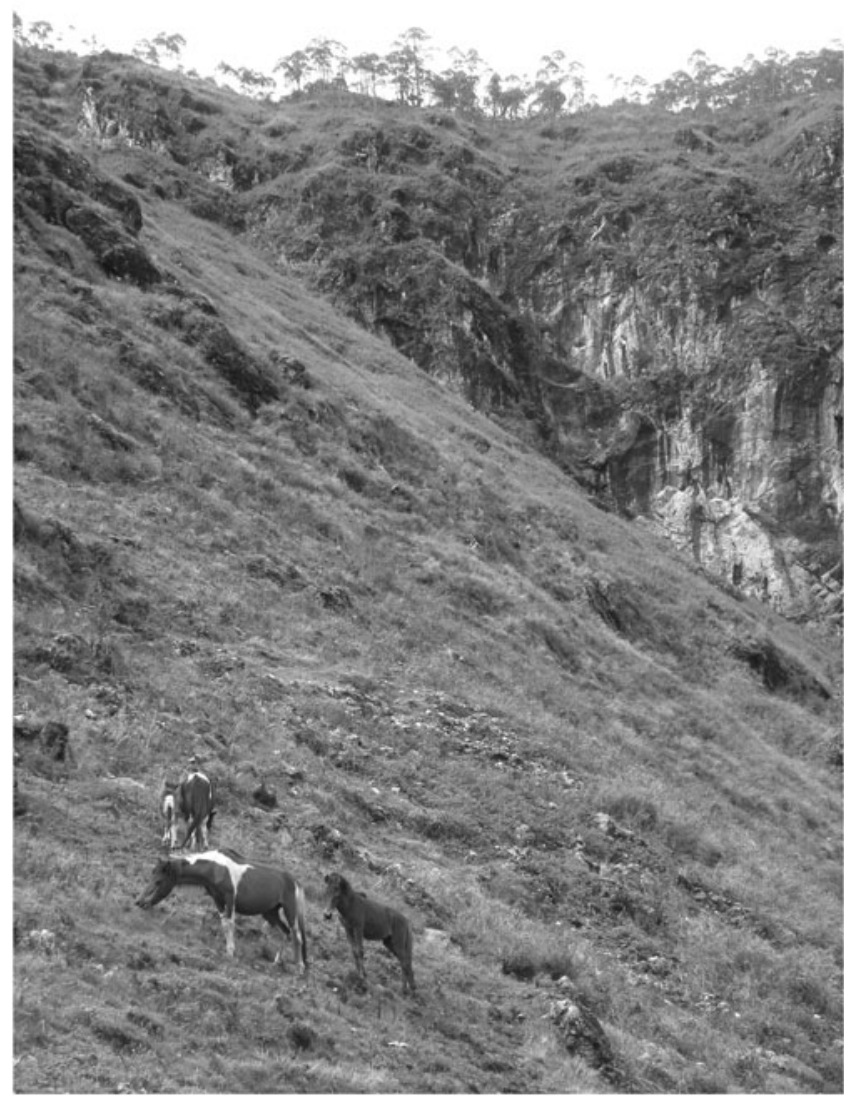

Figure 3. Several bush warblers were recorded singing from these Themeda-dominated grassy slopes above the Hatu Builico valley (1,950 m), Timor-Leste; free-ranging horses (shown here), as well as cattle, water buffalos and goats accessing green 'pick' in all but the most topographically protected areas.

were no significant differences between the maximum frequency of Alor birds, compared to recordings of Russet Bush Warbler, but most other paired comparisons were significantly different (Table 3).

Table 2. Summary measurements of maximum and minimum frequency of songs with range for selected South-east Asian Locustella Bush Warbler taxa.

\begin{tabular}{llll}
\hline Population & $\begin{array}{l}\text { No. Individual } \\
\text { birds (no. bouts) }\end{array}$ & $\begin{array}{l}\text { Mean max. } \\
\text { frequency }(\mathrm{KHz})\end{array}$ & $\begin{array}{l}\text { Mean min. } \\
\text { frequency }(\mathrm{KHz})\end{array}$ \\
\hline Timor & $6(30)$ & $4,761(4,167-5,382)$ & $2,928(2,558-3,125)$ \\
Alor & $4(15)$ & $4,980(6142-5,816)$ & $3,233(2,558-3,990)$ \\
Bali (montis) & $1(4)$ & $4,644(4,514-4,688)$ & $1,780(1,649-1,823)$ \\
Java (montis) & $2(10)$ & $3,735(3,541-5,816)$ & $2,412(2,148-2,739)$ \\
Luzon (seebohmi) & $3(15)$ & $4,710(4,430-4,959)$ & $2,894(2,685-3,299)$ \\
Thailand, Vietnam, & $3(15)$ & $5,288(4,841-5,811)$ & $3,721(3,193-3,946)$ \\
$\quad$ Burma (mandelli) & & & \\
\hline
\end{tabular}




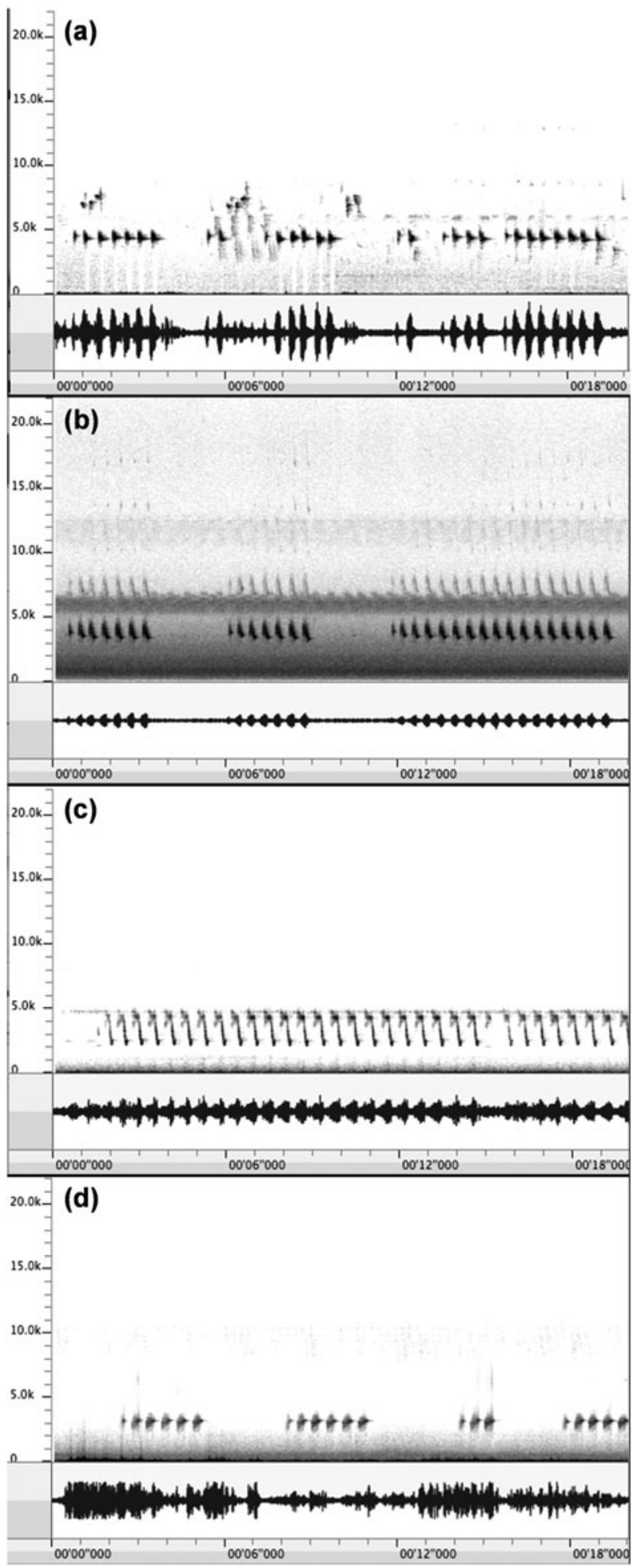

Figure 4. Sonograms showing several bouts of song strophes, and then (below) two individual strophes for (a) Alor, (b) Timor (c) Bali, and (d) Java. Note - in (a), the input level was too high during recording, resulting in clipped frequency curves and possibly also in the 'high frequency shadows'. 

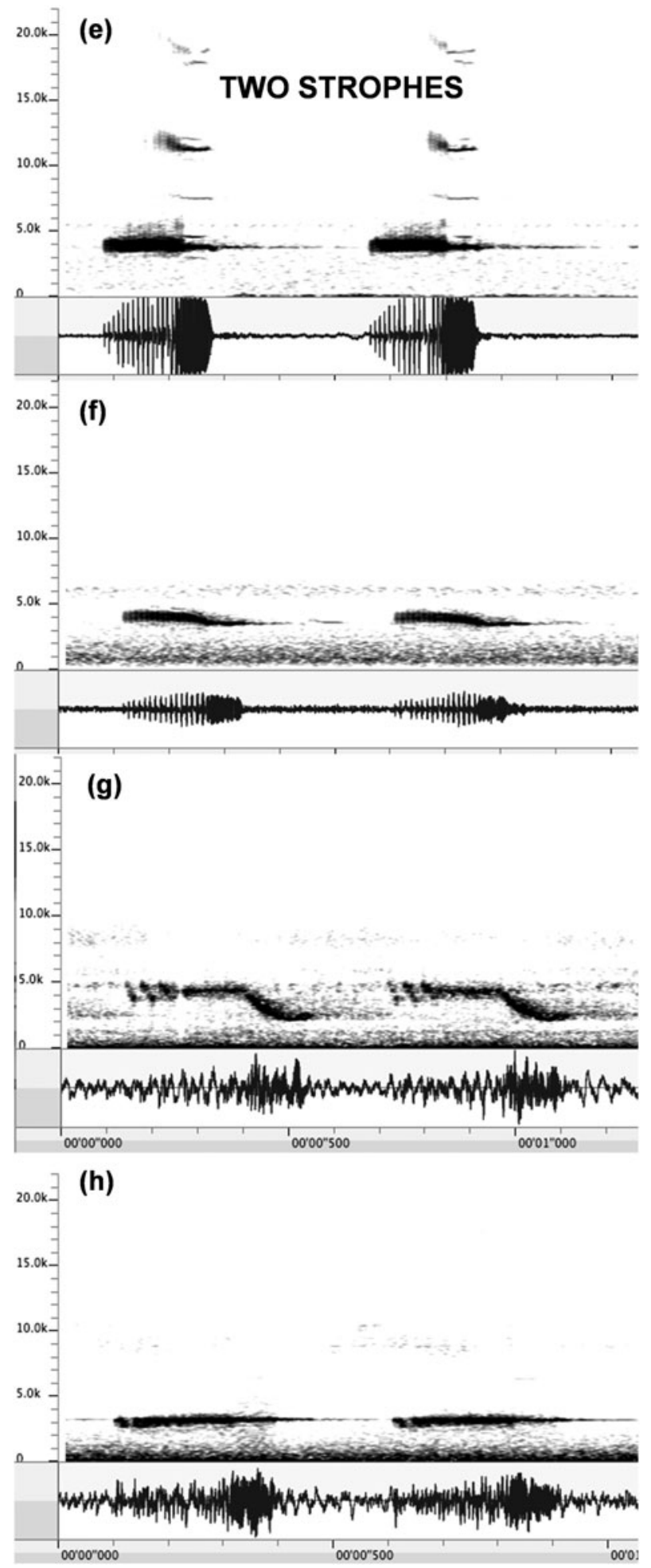

Figure 4. Continued. 

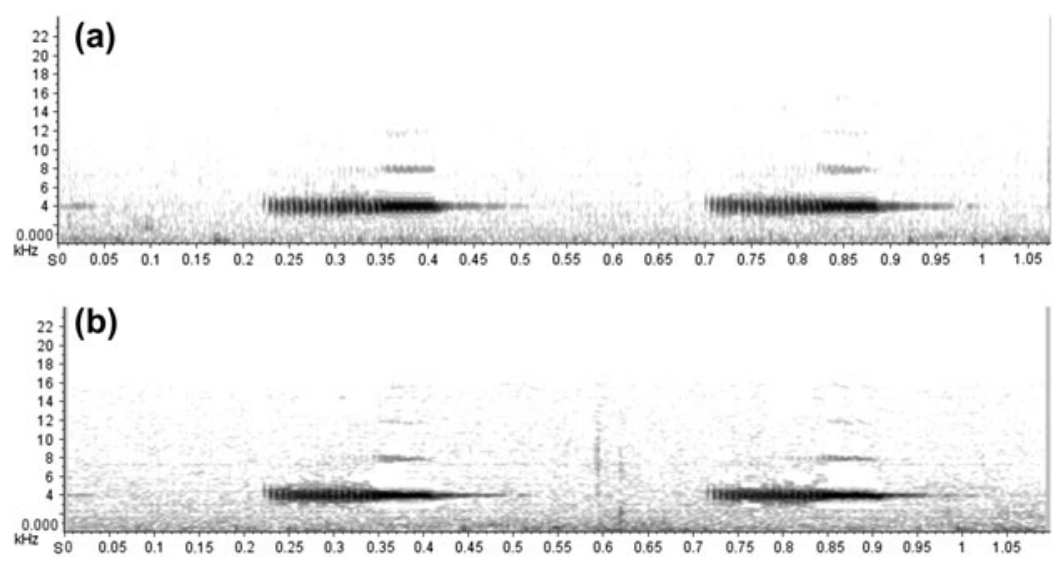

Figure 5. Sonograms showing several bouts of song strophes, and then (below) two individual strophes for (a) Russet Bush Warbler L. mandelli (Burma, Per Alström, sourced from: www. avocet.zoology.msu.edu); and, (b), Benguet Bush Warbler L. seebohmi (Luzon, Philippines, Paul Noakes, sourced from: www.xeno-canto.org).

\section{Call}

One bird on Alor gave alarm calls in response to playback comprising hundreds of moderately high pitched Turdus-like chip notes (3-4 notes per second), and two birds on Timor gave similarly pitched and spaced notes without playback use (Fig. 6a). A second call on Timor was a rapidly produced frantic high-pitched whistle (Fig. 6b).

\section{Behaviour and detectability}

Bush warblers on both Alor and Timor were skulking and typically observed for short periods $(<0.2-0.5 \mathrm{sec})$, particularly after playback. Our brief direct observations on Alor noted a large, buff-brown, long-tailed bush warbler. Birds were observed to walk or scurry, mouse-like, on the ground on thin shrub and grass stems, in the understorey below $1.5 \mathrm{~m}$. They vocalised from dense understorey, occasionally moving a little higher when agitated, but they were not significantly easier to observe while singing. Although they can fly, they do so rarely and probably mostly under cover. Birds were heard calling throughout the day on both Alor and Timor, but most frequently in the first $3 \mathrm{hr}$ after dawn and $2 \mathrm{hr}$ before sunset. Some individual Timor birds sang continuously for at least 5 minutes, typically rested for $1-5 \mathrm{~min}$ and then continued with another song bout, repeatedly for up to $\mathrm{I} \mathrm{hr}$.

Birds were loud and could be readily heard from a distance of at least 70-100 $\mathrm{m}$. On Timor, one previously located bird could be heard singing from a measured distance of $453 \pm 7 \mathrm{~m}$ (using

Table 3. Paired comparisons of mean maximum song frequency (given first) and mean minimum song frequency (given second) for selected Bush Warbler populations. Values shown are significance levels: n.s., not significant (highlighted in bold).

\begin{tabular}{lllll}
\hline Population & Alor & Java (montis) & Luzon (seebohmi) & $\begin{array}{l}\text { Thailand, Vietnam, } \\
\text { Burma }(\text { mandelli) }\end{array}$ \\
\hline Timor & n.s $/<$ 0.001 & $<$ 0.001 $/<0.001$ & n.s. $/ 0.02$ & $<0.001 /<0.001$ \\
Alor & & $<$ 0.001 $/<0.001$ & n.s $/<0.001$ & n.s $/<0.001$ \\
Java (montis) & & $<0.001 /<0.001$ & $<0.001 /<0.001$ \\
Luzon (seebohmi) & & & $<0.001 /<0.001$ \\
\hline
\end{tabular}


(a)

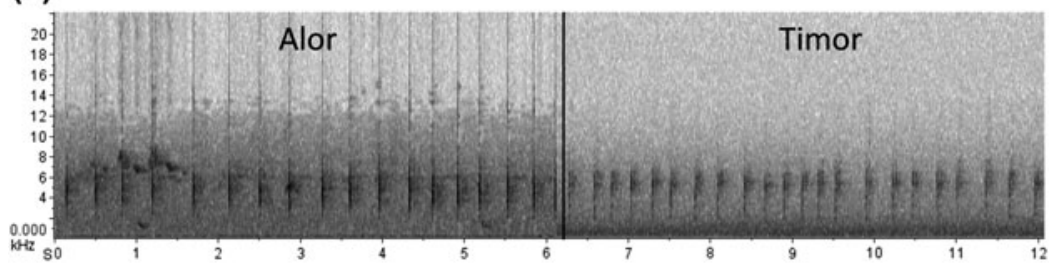

(b)

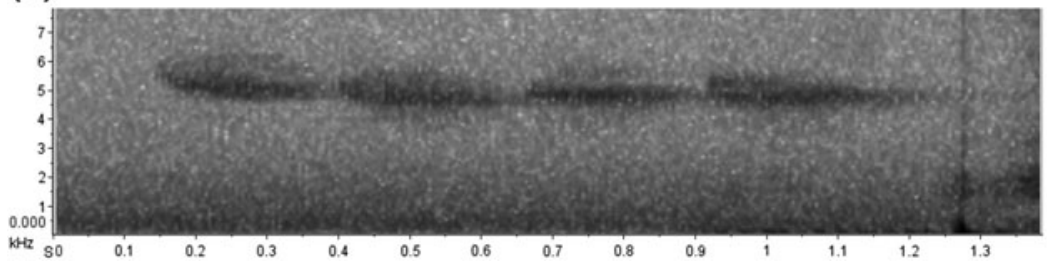

Figure 6. Audio sonograms of bush warbler alarm calls: (a) Turdus-like chip (alarm) notes given by birds on Alor and Timor (x-axis tick marks at $0.5 \mathrm{~s}$ ); (b) rapid high pitched whistle apparently given in alarm by Timor birds ( $\mathrm{x}$-axis tick marks at $0.1 \mathrm{~s}$ ).

the 'go to' function in GPS) and on Alor one bird was heard from a distance of $336 \pm 1$ om. There appeared to be some seasonal and inter-island variation in response to playback. The bird discovered by FV on Alor responded strongly to playback of a recording of Russet Bush Warbler B. mandelli from Thailand. Birds on Timor were substantially less responsive to playback than Alor birds.

\section{Distribution, abundance and habitat use}

Bush warblers were unrecorded from Wahwah and Tanglapui Timur on Alor, from Mundo Perdido and Mount Mutis on Timor, from Mount Wasbila and Mount Sirung on Pantar, Mount Manucoco on Atauro and Mount Ili Mosu on Wetar (Fig 1). Wahwah is dominated by dense forest regrowth below $700 \mathrm{~m}$ with no grassland and we expect that bush warblers are genuinely absent, whereas habitat at Tanglapui Timur is similar to Subo-Manmas and Mainang with extensive Eucalyptus woodland with a grassy understorey. At Mount Mutis tall grassland occurs on steep slopes making access difficult which may have affected bush warbler detection. The Mundo Perdido area is dominated by tropical forest and tall grassland is absent. On Pantar, suitable grassy habitat was present at Mount Wasbila, but Mount Sirung was probably too low elevation for bush warblers. Although Mount Manucoco reaches $995 \mathrm{~m}$, only about $4 \mathrm{~km}^{2}$ of habitat lies above $700 \mathrm{~m}$, and much of this is tropical forest rather than grassland. Habitat at Mount Ili Mosu appeared identical to sites on Alor where bush warblers were recorded.

On Alor, six to eight singing male birds were recorded over about 200 ha at Subo-Manmas, and seven birds were recorded in about 50 ha at Mainang. Habitat here was dominated by Imperata cylindrica tall grassland (to $1.5 \mathrm{~m}$ ) mixed with siam weed Chromalaena odorata, directly adjacent to tree crops including candlenut Aleurites moluccana, cloves Eugenia aromaticum, and low E. alba or E. urophylla savanna woodland ( $13 \mathrm{~m}$ tall, with a dense understorey of grasses, ferns, weeds and shrubs) (Fig. 2). We did not systematically collect abundance data, but singing birds were typically 50-100 $\mathrm{m}$ apart suggesting that they occupy small territories of about $1-2 \mathrm{ha}$, and that they occur at relatively high densities. During repeat visits to sites on Alor and Timor we found that birds were typically recorded within about 30-50 $\mathrm{m}$ of previous observations (assuming that these were the same individual) confirming that they maintain small permanent territories.

All birds were recorded on topographically complex slopes and ridges above broad upland valleys, and were absent from extensive plateaus above the valleys. Bush warblers were also 
(a)
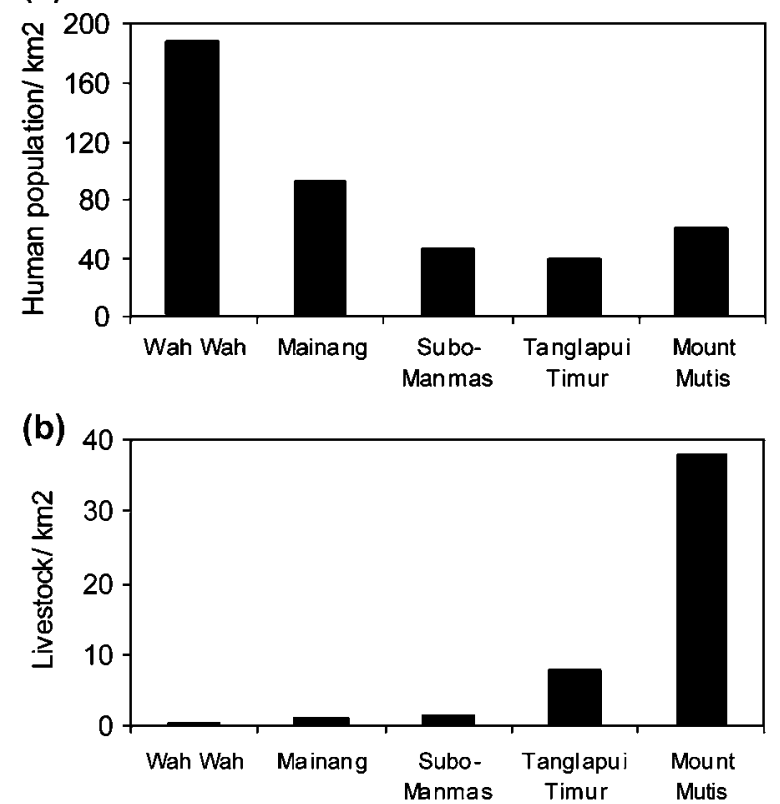

Figure 7. Comparison of (a) livestock (cattle plus horse) density, and, (b) human population density for Alor and Timor sites (data shown are means for the sub-districts covering the sites; sourced from Badan Pusat Statistik 2009a,b).

recorded in Eucalyptus savanna woodlands dominated by E. alba and E. urophylla, but were apparently absent from these habitats when not in close $\left(<_{1} \mathrm{~km}\right)$ proximity to regrowth forest. On Alor birds were recorded at 859-1,250 m (859-930 $\mathrm{m}$ at Mainang and 900-1,250 $\mathrm{m}$ at SuboManmas), while on Timor birds were recorded at 1,720-2,100 m. On Timor, birds were singing about Hatu Builico village along a $2.5 \mathrm{~km}$ length of a river valley (over about $250 \mathrm{ha}$ ) in discrete patches (mostly $<2$ ha) of Themeda sp. dominated grassland (mixed with low sedges and weeds, or at edge of E. urophylla woodland and agricultural land with dense tangled understorey) on steep and topographically protected slopes (Fig. 3). Birds were generally absent from extensive E. urophylla dominated woodland that occurs widely in the valley and in E. orophila woodland near the summit of Mount Ramelau.

\section{Threats to habitat}

There were substantial differences in the intensity of land use between sites and islands. On Timor, livestock density (cattle and horses) was an order of magnitude greater at Mount Mutis (Fatumnasi sub-district) than most of the Alor sub-districts (Fig. 7). On Timor, cattle and horses are mostly free-range but on Alor no free-ranging livestock were observed because cattle were tethered with ropes. The frequency and extent of wildfires is probably greater on Timor, to provide fodder for stock. Tall grass is also collected as a roofing material on Timor, but we have no information on whether this might also be a threat to tall grassland habitat.

\section{Discussion}

Our field observations and subsequent analysis of field recordings show the high degree of similarity of the territorial song of the Alor and Timor bush warblers to each other, and to populations in the 
Philippines in particular, as well as Java and Bali, and to the Russet Bush Warbler of mainland Asia. Recent molecular studies have shown that divergences between L. montis and L. mandelli are so slight that their status as separate species needs to be studied further (Alström et al. 2011). Based on an analysis of songs, our study therefore places the Timor and Alor populations close to Benguet Bush Warbler and presumably to Javan Bush Warbler and Russet Bush Warbler (P. Alström in litt. 2011). Genetic analyses are now needed to confirm the taxonomic affinities of the Timor and Alor birds. This is remarkable given the degree of isolation from the nearest populations on Java, Bali and the Philippines and from mainland Asian populations (c.2,500 km). Ancestral bush warblers presumably island-hopped from Java through Bali, along the Lesser Sunda chain to Timor, with many intervening island populations apparently extinct (Kennerley and Pearson 2010) or alternatively, island-hopped south from a Philippines source.

The Alor population is currently well isolated from Timor (c.10o km between sites), and these islands have never been connected, and would not have been substantially closer during glacial maxima (Voris 2000). The populations have little chance of interbreeding and therefore should be considered as independent, evolutionarily significant units. Future work using a molecular approach is needed to determine the precise relationships of the Alor and Timor populations within the Benguet Bush Warbler L. seebohmi complex, where L. mandelli presumably belongs.

There were substantial differences in habitat use by bush warblers on Alor compared to those on Timor that presumably result from island-specific differences in habitat availability, elevation and land-use pressure. Timor is substantially higher than Alor and there was no overlap in elevation use by bush warblers. On Alor, bush warblers were repeatedly recorded on predictable topographic features: the slopes and ridges above broad valleys where complex topography and intense land use (including protection of valuable tree crops from fire) produces a dense grass or shrubby understorey. Birds appear to occur in discrete sub-populations that may be isolated by distances of $1-10 \mathrm{~km}$ by unused habitat at the same elevation of occupied habitat. Bush warblers were absent from the coastal highland slopes and valleys and also from topographically simple highland plateaus (900-1,200 m) which had probably been subjected to repeated hot wildfires. On Timor, bush warblers were only recorded from treeless grassland or grassland beneath Eucalyptus woodland.

All three bush warbler localities were discovered incidentally after hearing their characteristic song which in typical conditions can be heard from a distance of $70-200 \mathrm{~m}$ and up to $500 \mathrm{~m}$ in river valleys. Use of playback is now increasingly common, but presumably none of the many visitors to Mount Mutis (Dickinson et al. 2000) used playback to elicit responses from bush warblers during visits. Songs of bush warblers are becoming better known with their increased availability on CDs (Scharringa 200o) the web (e.g. http://avocet.zoology.msu.edu; http://www. xeno-canto.com) and guidebooks (Kennerley and Pearson 2010). Furthermore, because habitat for the Timor bush warbler was unknown, most visitors are unlikely to make a special effort to access montane grassland or shrub (that are poor in forest specialised endemic birds) in the hope of recording a bush warbler. On Alor and Timor, bush warblers also prefer patchily distributed shrubby or grassland habitat, which increases the likelihood of overlooking birds.

There has been little survey effort on the mountains of Timor and Alor, except for Mount Mutis on Timor (Jepson and Ounsted 1997), Mount Mundo Perdido in Timor-Leste (Santana et al. 2009) and the Apui (Johnstone and Darnell 1997) and Tanglapui Timor sites on Alor (Trainor 2005). Our mountain field searches at Mount Ramelau, Mainang and Wahwah, Pantar Island, Atauro Island and Wetar Island are the first at those sites as far as we are aware. We highlight montane sites with bush warbler potential below and in Figure 1 . New information on the song and ease of detection of the Alor and Timor bush warblers will make future field surveys easier, with rapid roadside assessments (and playback experiments) feasible through the mountains of Alor, and point counts (to determine relative abundance and, potentially, density) in combination with playback, a suitable method on both Alor and Timor. Mist-netting to capture birds and collect genetic material and morphometrics is also needed.

Bush warblers were patchily distributed on Alor: they were unrecorded at Tanglapui Timur (Mount Koya Koya) despite suitable habitat. This site needs further attention (Fig. I), as do the 
hills to the south and east of Mainang. On Mount Mutis, West Timor, we used playback in a variety of habitats from $1,300 \mathrm{~m}$ to the summit at $2,400 \mathrm{~m}$. The grassy southern slopes $(1,400-2,000 \mathrm{~m})$ were surveyed briefly with playback, but this habitat is distant from tracks leading to the montane forest that is typically targeted by recreational birdwatchers and has probably not previously been explored. P. Andrew camped on the summit of Mutis - an area characterised by montane forest and Eucalyptus woodland with a sparse understorey and little grass. There is an unconfirmed Mount Mutis sighting (elevation unknown) of a flushed Locustella bush warbler on 22 July 1999 (C. Doughty in litt. 2010) giving hope that a population does persist there. A high priority for further West Timor survey is Mount Timau $(1,737 \mathrm{~m})$. This important area of evergreen forest lying $32 \mathrm{~km}$ to the west of Mount Mutis was surveyed in April 1999 (Lesmana et al. 2000), and 2008 (C. Robson in litt. 2010) but deserves specific searches for bush warblers.

In East Timor, land above $1,500 \mathrm{~m}$ totals $403 \mathrm{~km}^{2}$, with the largest mountain areas after Mount Ramelau being Mount Matebian (2,315 m), Mount Cablaque (2,491 m), Mundo Perdido $(1,705 \mathrm{~m})$, Mount Taroman ( $1,641 \mathrm{~m})$, Mount Cailaco and associated Mount Tapo (1,749 $\mathrm{m}$ and $1,775 \mathrm{~m}$ ) (Figure 1; Trainor 2010). The avifaunas of Mount Matebian and Mount Cablaque have never been surveyed, but both have patches of tall grassland (J. Teixeira in litt. 2010) seemingly suitable for bush warblers. Mount Cablaque is an isolated mountain stack surrounded by valleys, but lies only $8 \mathrm{~km}$ from Mount Ramelau. Mundo Perdido lacks suitable tall grass habitat and after 21 days of survey (Santana et al. 2009) bush warblers are probably genuinely absent. Mount Cailaco and Mount Taroman are small isolated mountains with little high elevation $(>1,500 \mathrm{~m})$ habitat. Neither has previously been ornithologically explored and they would be worth some attention.

On Pantar the ornithologically unexplored Eucalyptus and grass-clad Mount Delaki (1,3I8 m), adjacent to Mount Sirung, is well-connected to numerous hills above $700 \mathrm{~m}$ along the east coast of the island and might be suitable for bush warblers. Wetar is a rugged island with extensive montane habitat $\left(200 \mathrm{~km}^{2}\right.$, or $5.5 \%$ of the $3,600 \mathrm{~km}^{2}$ island is above $\left.1,000 \mathrm{~m}\right)$ and has a nearperfect sub-set of Timor's avifauna (Trainor et al. 2009). The two most extensive mountain regions remain unexplored and deserve attention. These are the inaccessible Tenagatu mountain range (Naumatang gunung or Arnau) in the south-west and Mount Lalawu and Mount Situfula (in villages of Uhak and Tomliapat) in the north-east (Fig. 1). Very few montane birds have been recorded on Wetar (Trainor et al. 2009, CRT unpubl. data.) which possibly relates to the recent and rapid uplift of the island (Scotney et al. 2008).

High grazing pressure and repeated fires, as mentioned previously for Mount Mutis (Dickinson et al. 2000) ensure that there is little or no suitable habitat available for bush warblers over much of Timor's montane habitat, including Mount Ramelau, except on steep slopes. The rarity of suitable grassland habitat on Mount Ramelau is of serious conservation concern as this mountain must cover a high proportion (c.50\%) of the land over $1,500 \mathrm{~m}$ on Timor Island. Tall and presumably ungrazed grassland mostly occurs in small patches of less than 1 ha in the Hatu Builico valley. The total area of ungrazed or lightly grazed grassland or shrubland in Timor-Leste is likely to be substantially less than 2,0oo ha. If a pair of bush warblers occupied territories of about 2 ha, then the total population might be less than 1,000 pairs.

As the most isolated representatives, and possibly most divergent members of the Benguet Bush Warbler complex, the populations on Alor and Timor deserve specific conservation attention, including further searches to define distribution and habitat use. On Timor, for example, bush warblers are the only one of 11 montane bird species that depends on grassland rather than forest. Their ongoing persistence may therefore require specific management of grassland habitat, particularly given the intensity of livestock grazing. The status of Timor Bush warbler as 'Near Threatened' (www.redlist.org) will also require re-evaluation. There are no protected areas covering montane habitat on Alor, but the Mount Ramelau area is currently recognised as a 'Protected Wild Area' and Important Bird Area to protect montane habitats and wildlife (UNTAET 2000, Trainor et al. 2007), but there is little on-ground management. Mount Mutis is currently designated as a National Park, however threats identified over the past 20 years, primarily intensive grazing pressure and wildfires (Dickinson et al. 2000), continue to threaten 
habitats and wildlife. There are few threats to bush warbler habitat on Alor, as far as we are aware, but ongoing assessments are needed.

\section{Acknowledgements}

Thanks to Jez Bird and Pamela Rasmussen for comments and suggestions; Per Alström who provided useful suggestions which improved the article during review; Ian Cowie for identifying some plants; George Sangster for providing literature; Magnus Jaderblad for allowing use of his Bali recording (facilitated by Peter Kennerley), and Frank Lambert and Bas van Balen (via XenoCanto) made available their Javan recordings. Jose Teixeira provided photos and information on grassland on Mount Cablaque and Matebian, and Chris Doughty and Craig Robson provided information on their West Timor observations. FV thanks Veerle Dossche for companionship during his first Alor visit. P.T. Batutua Tembaga Raya provided great logistical support for CRT's visit to the uplands of Wetar Island, with particular thanks to Chris Farmer.

\section{References}

Alström, P., Fregin, S., Norman, J. A., Ericson, P. G. P., Christidis, L. and Olsson, U. (2011) Multilocus analysis of a taxonomically densely sampled dataset reveal extensive nonmonophyly in the avian family Locustellidae. Mol. Phylog. Evol. 58: 513-526.

Badan Pusat Statistik (2009a) Timor Tengah Selatan in figures. Soe, West Timor: Badan Pusat Statistik.

Badan Pusat Statistik (2009b) Alor in figures. Kalabahi, Alor: Badan Pusat Statistik.

Birdlife International (2010) The BirdLife checklist of the birds of the world, with conservation status and taxonomic sources. Version 3. BirdLife International. Downloaded from http://www.birdlife.org/datazone.

Clements, J. F., Schulenberg, T. S., Iliff, M. J., Sullivan, B. L., Wood, C. L. and Roberson, D. (2011) The Clements checklist of birds of the world: Version 6.6. Downloaded from http:// www.birds.cornell.edu/clementschecklist.

del Hoyo, J., Elliott, A., and Christie, D. A., eds. (2006) Handbook of the birds of the world, vol. 11. Old world flycatchers to Old World warblers. Barcelona: Lynx Edicions.

Delacour, J. (1952) The specific grouping of the bush warblers Bradypterus luteoventris, Bradypterus montis and Bradypterus seebohmi. Ibis 94: $362-363$.

Dickinson, E. C., Rasmussen, P. C., Round, P. D. and Rozendaal, F. (2000) Systematic notes on Asian Birds. 1. A review of the russet bushwarbler Bradypterus seebohmi (OgilvieGrant, 1895). Zool. Verhandel. 331: 11-64.
Hartert, E. (1898) On the birds of Lomblen, Pantar, and Alor. Novit. Zool. 5: 455-465. Hellmayr, C. E. (1914) Die Avifauna von Timor. Pp. 1-112 in C. B. Haniel, ed. Zoologie von Timor: Ergebnisse der unter Leitung von Joh. Wanner im Jahre 1911 ausgeführten Timor-Expedition. Stuttgart: Nagele und DR. Sproesser.

Holmes, D. A. (1995) Additions to the avifauna of Pulau Alor, Nusatenggara. Kukila 7: 155156.

Jepson, P. and Ounsted, R. (1997) Birding Indonesia: a birdwatchers guide to the world's largest archipelago. Singapore: Periplus Editions.

Johnstone, R. E. and Darnell, J. C. (1997) Description of a new subspecies of bushwarbler of the genus Cettia from Alor Island, Indonesia. Western Austral. Nat. 21: 145-151.

Kennerley, P. and Pearson, D. (2010) Reed and bush warblers. London: Christopher Helm and A \& C Black.

LeCroy, L. (2008) Type specimens of birds in the American Museum of Natural History. Part 7. Passeriformes: Sylviidae, Muscicapidae, Platysteiridae, Maluridae, Acanthizidae, Monarchidae, Rhipiduridae, and Petroicidae. Bull. Am. Mus. Nat. Hist. 313: 1-287.

Lesmana, D., Trainor, C. and Gatur, A. (200o) The importance of forest areas in West Timor: a review of biodiversity and socioeconomic information based on rapid surveys. Bogor: PKA/BirdLife International/ WWF. (Report No 13). 
Mayr, E. (1944) The birds of Timor and Sumba. Bull. Am. Mus. Nat. Hist. 83: 126-194.

Noske, R. A. and Saleh, N. (1996) The conservation status of forest birds in West Timor. Pp. $65-74$ in D. J. Kitchener and A. Suyanto, eds. Proceedings of the first international conference on eastern Indonesian-Australian vertebrate fauna. Perth, Australia and Manado, Indonesia: Western Australian Museum-LIPI.

RePPProT [Regional Physical Planning Project for Transmigration]. (1989) Review of Phase I Results Maluku and Nusa Tenggara. Jakarta: Departemen Transmigrasi.

Santana, F., Pinto, P., Hornay, C., Freitas, A., Pereira, S., Ferreira, F. S. and Trainor, C. R. (2009) Mount Mundo Perdido: a profile of its biodiversity and conservation. Cambridge, UK: Birdlife International.

Scharringa, J. (2000) Birds of tropical Asia, sights and sounds. Westernieland, The Netherlands: Bird Songs International BV.

Scotney, P. M., Roberts, S., Herrington, R. J., Boyce, A. J. and Burgess, R. (2005) The development of volcanic hosted massive sulphide and barite-gold orebodies on Wetar Island, Indonesia. Mineralium Deposita 40: 76-99.

Trainor, C. R. (2005) Species richness, habitat use and conservation of birds of Alor island,
Lesser Sundas, Indonesia. Emu 105: 127135.

Trainor, C. R. (2010) Timor's fauna: the influence of scale, history and land-use on faunal patterning. PhD Thesis, Charles Darwin University, Darwin.

Trainor, C. R., Imanuddin, A., Verbelen, P. and Walker, J. S. (2009) The birds of Wetar, Banda Sea: one of Indonesia's forgotten islands. BirdingASIA 10: 78-93.

Trainor, C. R., Santana, F., Rudyanto, Almeida, A. F., Pinto, P. and de Olivera, G. F. (2007) Important Bird Areas in Timor-Leste: key sites for conservation. Cambridge: BirdLife International.

Trainor, C. R., Santana, F., Pinto, P., Xavier, A. F., Safford, R. and Grimmett, R. (2008) Birds, birding and conservation in TimorLeste. BirdingASIA 9: 16-45.

UNTAET (2000) On protected places. Regulation NO. 2000/19 on protected places.

Voris, H. K. (2000) Maps of Pleistocene sea levels in Southeast Asia: shorelines, river systems and time durations. J. Biogeog. 27: 1153-1167.

White, C. M. N. and Bruce, M. D. (1986) The birds of Wallacea (Sulawesi, the Moluccas and Lesser Sunda Islands, Indonesia). An annotated checklist. London: British Ornithologists' Union. (Checklist 7).

\section{COLIN R. TRAINOR*}

School of Environmental and Life Sciences, Charles Darwin University ogog, Northern Territory, Australia

Current Address: ENV. Australia, Level 1, 503 Murray St, Perth, Western Australia, Australia.

\section{PHILIPPE VERBELEN}

Torrekenstraat 41, 9820 Munte-Merelbeke, Belgium.

\section{SERGE HOSTE}

Department of Inorganic and Physical Chemistry WEo6V University of Ghent, Krijgslaan 281, 9000 Ghent, Belgium.

*Author for correspondence; email: halmahera@hotmail.com

Received I February 2011; revision accepted 23 May 2011;

Published online 20 December 2011 